УДК 159.942 .5

DOI https://doi.org/10.32838/2709-3093/2021.3/11

Сердюк Н.I.

Бердянський державний педагогічний університет

\title{
АТРАКЦЙНІСТЬ ЯК ЗАПОРУКА ЕФЕКТИВНОЇ КОНСУЛЬТАТИВНОЇ ДІЯЛЬНОСТІ ПСИХОЛОГА
}

У статті розглядається вагомість атрактивності психолога під час упровадження ефективного консультативної взаємодії із клієнтами. Подано значення поняття «атракційність», під яким розуміється властивість людини викликати до себе симпатію і довіру в інших людей. Висвітлено теоретичний аналіз досліджень науковиів, у яких вивчались особливості прояву атрактивності психолога, визначались чинники, що викликають прихильності до особистості психолога, встановлювались співвіднесення атрактивності з іншими професійними характеристиками психолога. Зазначено впливовість атрактивності психолога під час консультативної роботи зі складними клієнтами та їхніми психологічними механізмами захисту. У результаті узагальнення визначено, що атрактивність психолога залежить від його особистого ставлення до консультативного прочесу, уміння залучати людей до себе, відчувати себе вільно під час проведення консультації, проявляти здатність до емпатії. Виокремлено найбільш значущі вербальні форми поведінки (саморозкриття психолога, прояв схожсості життєвих иінностей, звернення на ім'я до клієнта, виразність мовлення психолога тощо) та невербальні форми поведінки (позитивні кивки головою, жести рук, рукостискання, контакт очима, вираз обличчя, міміка, нахил тулуба тощо), щьо позитивно та дієво впливають на атрактивність психолога і психологічну консультативну діяльність. Висвітлено результати сучасного дослідження щодо привабливості голосу віртуального консультанта (чат-бот), який виконує роль психолога та проводить психологічне консультування з реальними людьми. Визначено завдання на перспективу, що полягає у трунтовному емпіричному досліджені уявлення про атракиійність психолога серед клієнтів психологічного консультування, психологів-практиків та майбутніх психологів, ї̈ вплив на результативність консультування.

Ключові слова: атрактивність, психолог, консультування, вербальна поведінка, невербальна поведінка.

Постановка проблеми. Сучасні вимоги до професійної діяльності психолога передбачають наявність hard skills (навички самостійно планувати та здійснювати психологічне дослідження, організовувати та надавати психологічну допомогу тощо), soft skills (навички міжособистісного спілкування, емоційної регуляції, ситуаційної обізнаності, гнучкості й адаптивності тощо), особистісних характеристик (спостережливість, терпимість, гуманність, відповідальність, об' єктивність тощо). У практичній психології саме особистість психолога має істотний вплив на його професійну діяльність, як наслідок, це підкреслює важливість таких специфічних якостей, як: інтелектуальність, емпатійність, рефлективність, альтруїстичність, атрактивність тощо. Кожна із зазначених вище характеристик має суттєвий вплив на діяльність психолога, проте саме атрактивність (привабливість) психолога викликає особливий інтерес та прагнення дослідити іiі значення у процесі надання психологічної допомоги іншим людям.
Більшість науковців під час вивчення питання атрактивності звертали свою увагу на феномен атракції, інтерпретували його 3 різних наукових позицій, а саме: як явище, що виникає під впливом рефлективних чинників (3. Фрейд, У. Шутц, $\mathrm{X}$. Салліван); чинник, що визначає привабливість однієї людини для іншої через схожість їхніх настанов і цінностей (Д. Бірн, Дж.Л. Клоре й інші); механізм формування привабливості, першого враження (О. Бодальов); ключову складову частину виникнення міжособистісних стосунків (Ф. Хайдер, Т. Ньюком, 3. Рубін, В. Куніцина, І. Волков, Е. Кузьмін, М. Пікельникова, Н. Федотова й інші); компонент міжособистісного сприймання (Г. Андреєва), чинник розвитку і становлення дружби (І. Кон); симпатію, що визначає емоційну позитивну настанову особистості (М. Обозов, Н. Казарінова); важливий компонент соціального статусу (3. Кіреєва) й інші [11].

Аналіз останніх досліджень i публікацій. Атрактивність як особистісну якість 
досліджували В. Стормер Г. Алварез [26] через взаємозв'язок психічних процесів та сприйняття атрактивності особистості, А. Кленчу [5] - як значущу емоційно-комунікативну складову частину особистості старшого юнацького віку, Б. Мещеряков, Д. Ющенкова [8] - як фізичну привабливість жіночих обличь, Я. Верещинська - як естетичний компонент соціальної перцепції [4] тощо. Взаємозв'язок фізичної атрактивності з упевненістю особистості розглядали Х. Мелло, Т. ГарсіяМаркес, П. Бріньоль, А. Канцалак, Р. Петті [21], із самооцінкою та розумовими здібностями - С. Сім, Дж. Саперія, Дж. Браун і Ф. Берньєрі [25], інші.

Значення атрактивності в роботі психолога вивчається також усебічно. Так, у працях С. Бахарі, М. Саада й А. Саллех [15] висвітлювався вплив зовнішньої привабливості психолога на консультативний процес, поведінкові ознаки атрактивності психолога досліджували Ч. Клейборна та Р. Нерісон [23]. орейські науковці Х. Кім, М. Ча й Е. Джі [19] провели інноваційне та сучасне дослідження в напрямі психологічного консультування, вони вивчали привабливість голосу віртуального агента (чат-бот), який виступає в ролі психолога та проводить психологічне консультування. Г. Хомич, Ю. Шамардак [12], М. Міллер та Д. Веллс [22] розглядали значення атракції як складової частини міжособистісної перцепції у професійній діяльності психолога.

Дослідження привабливості ще не вичерпали всієї актуальної проблематики i, безсумнівно, зберігають велике теоретичне і практичне значення. Аналіз літератури 3 питань атрактивності психолога дозволяє зробити висновок, що їх не досить вивчено. Це й зумовлює необхідність вичерпного теоретичного аналізу досліджуваної особистісної якості психолога.

Постановка завдання. Метою статті є теоретичний огляд наукових досліджень щодо особливостей прояву атрактивності у професійній діяльності психолога-консультанта.

Виклад основного матеріалу дослідження. У широкому розумінні у «Великому психологічному словнику» визначено поняття «атракційність» як властивість людини викликати до себе симпатію і довіру в інших людей $[1$, с. 48]. У вузькому, специфічному розумінні атрактивність психолога має тотожне значення.

Існує низка характеристик, які роблять психолога-консультанта впливовим в очах клієнтів. На думку С. Стронга, атрактивність психолога базується на усвідомленні схожості між клієнтом та психологом-консультантом [27]. У клієнта починає виникати симпатія та прихильність до психолога, якщо він спілкується 3 ним доступними, зрозумілими словами, без уживання професійних термінів, його висловлювання чіткі та доступні для сприймання [17, с. 159]. Кілька досліджень показали, що вияв схожості та симпатії передається за допомогою різноманітних вербальних форм поведінки, як-от: саморозкриття психолога (Ч. Клейборн [23], Е. Даут, Д. Борото [16] та інші); схожість цінностей (С. Стронг [27], Р. Нерісон [23]), звернення на ім'я до кліснта (Е. Роббінс, Р. Хаас [24]) тощо.

Крім того, у дослідженнях, що вивчали значення невербальної поведінки психолога, було виявлено, що високий рівень невербальних сигналів формує вищу оцінку атрактивності психолога. До найбільш значущих невербальних сигналів психолога-консультанта було віднесено: позитивні кивки головою, жести рук, рукостискання, контакт очима, орієнтації плеча та нахил уперед, вираз обличчя (А. Барак, Дж. Паткін, Д. Делл [15]; Ч. Клейборн [23]; М. Лакросс [20]; Е. Роббінс, Р. Хаас [24] та інші). Підкреслено, що тембральна експресія також впливає на атрактивність психолога (Ч. Клейборн [23]). Крім того, з'ясовано, що саме невербальна поведінка більше сприяє виникненню атрактивності, ніж словесна поведінка (А. Барак, Д. Делл; Ч. Клейборн [15] та інші). Низка досліджень особливостей прояву симпатії й антипатії обгрунтовують це тим, що майже $55 \%$ невербальної інформації, що сприймається людиною, здатна впливати на виникнення симпатії до іншої людини [17].

Усі зазначені вище невербальні та вербальні форми поведінки справді мають великий вплив на процес психологічного консультування. Окрім цього, ефективність консультацій, на думку більшості науковців: I. Вачкова [3], Р. Кочюнаса [7], С. Васьківської [2] та інших, залежить від багатьох чинників, як-от: наявність у клієнта бажання та внутрішньої готовності вирішити проблему, розуміння ним шляхів ії подолання, відчуття комфорту та безпеки у процесі консультації, професіоналізм і досвід психолога, уміння дотримуватись правил консультування тощо [6]. До цього переліку можна віднести й атрактивність психолога. Свого часу Р. Мей стверджував, що консультантпсихолог повинен уміти залучати людей до себе, відчувати себе вільно в будь-якому оточені, проявляти здатність до емпатії, мати інші зовнішні атрибути чарівності. Ці вміння, на думку автора, з'являються тоді, коли спілкування із клієнтами приносить психологу задоволення, він бажає їм 
добра, проявляє до них щирий інтерес, цим самим він автоматично починає притягувати до себе інших, у психолога 3'являється так звана «особистісна чарівність», або атрактивність $[9$, с. 70$]$.

О. Шахматова в дослідженні основних властивостей особистості також зазначала, що саме атрактивність, толерантність і асертивність є максимально важливими у професійній діяльності фасилітаторів, до яких можна віднести й психологів. У іiі розумінні атрактивність розглядається як прагнення людини до позитивного ставлення до неї з боку інших людей, яке грунтується на власному позитивному ставленні до цих людей. Формування атрактивності, на іiі думку, залежить від емпатії, що забезпечує не тільки раціональне усвідомлення переживань іншого, співпереживання і співчуття, а й надання дієвої допомоги, підтримки в ситуаціях, які сприймаються людиною як важкі або навіть безвихідні. Емпатія сприяє збалансованості міжособистісних взаємин, робить поведінку людини соціально зумовленою та привабливою для інших [13].

М. Міллер і Д. Веллс у своїх працях зазначали важливість атрактивності психолога під час роботи зі складними клієнтами, що використовують різні механізми психологічного захисту у процесі проходження ними консультацій. Саме атрактивність, як особистісна якість психологаконсультанта, його позитивне ставлення під час консультування таких клієнтів викликають прихильність та довіру останніх, здатні впливати на створення спокійної, комфортної та доброзичливої атмосфери, що розслаблює людину, налаштовує на вирішення проблеми будь-якої складності [22].

Щодо значення психологічної атмосфери та поведінки психолога під час консультування провели грунтовне дослідження Р. Нерісон та Ч. Клейборн. У процесі якого клієнтам в університетському консультаційному центрі було запропоновано оцінити своїх психологів 3 погляду поведінкових ознак, пов'язаних із привабливістю й ефективністю консультативного процесу. Результати показали, що невербальна поведінка (вираз обличчя, міміка, жести) психолога була більш вагомою під час визначення його атрактивності та створення доброзичливого спілкування, ніж вербальна поведінка, однак виразність і емоційність мовлення психолога для респондентів також мали суттєве значення [23].

Не менш важливим $\epsilon$ вплив зовнішньої атрактивності психолога на розкриття інформації клієнтом, це зазначали С. Гарріс і А. Басбі. У своєму досліджені вони розкрили взаємозв'язок атрактивності психолога, статі клієнта, характеру проблеми та міри комфорту клієнта під час розкриття інформації в парному консультуванні. Учені дійшли висновку, що більшість учасників експерименту почуваються набагато комфортніше в разі промовляння інформації зовнішньо привабливому психологу, однак велике значення для них також має зміст їхнього звернення. Так, у них не виникав дискомфорт під час саморозкриття щодо проблем комунікативного характеру, а в разі обговорення потенційно незручних питань, що стосувались сексуальних взаємин із партнером, виникали труднощі та внутрішні бар'єри [18]. Тож, можна констатувати, що атрактивності належить одне із ключових місць у професійній діяльності психолога-консультанта.

С. Бахарі, М. Саад і А. Саллех вивчали думки клієнтів щодо впливу атрактивності психолога, його професійних навичок та дотримання ним етичних норм на результати консультування. За результатами експерименту вчені дійшли висновку, що виокремлені ними чинники позитивно корелюють із результатами консультування, адже це ті аспекти, на які необхідно звертати увагу психологу під час проведення консультацій із клієнтами. На думку вчених, здатність психолога гармонійно поєднувати власну атракційність із постійним удосконаленням професійних навичок та знань 3 етичних питань у консультуванні збільшує ефективність психологічної допомоги [14].

До подібних висновків дійшов і С. Стронг, він установив, що клієнти легше приймають думку психолога і менш схильні спростовувати її в тому разі, якщо останній сприймається як експерт, як атракційна та надійна людина. Під експертністю вчений мав на увазі сприйняття клієнтом психолога як компетентної людини, причому таке сприйняття залежало не від досвідченості психолога, а здебільшого від демонстрації ним певних вербальних і невербальних проявів. Атрактивність визначалася як сприйняття клієнтом психолога доброзичливою, приємною та привабливою людиною. Надійність розумілася як віра клієнта в те, що психолог не буде вводити його в оману або шкодити йому [27].

Усі висвітлені вище наукові спостереження розкривали реальний консультативний процес, у який залучені психолог і клієнт. Сучасна тенденція до діджиталізації більшості процесів, розвиток штучного інтелекту спонукали вчених Х. Кім, М. Ча, Е. Джі дослідити привабливість голосу віртуального консультанта (чат-бот), який 
виконує роль психолога та проводить психологічне консультування. У процесі експерименту респондентам було запропоновано взяти участь у консультативній бесіді 3 віртуальним агентом, який створено на основі штучного інтелекту та в який запрограмовано чотири голоси відповідно до віку та статі. Потім учасникам пропонувалось вказати, який вид голосу їм найбільше імпонував та приваблював. Результати цього дослідження вказують на те, що віртуальний консультант із жіночим голосом, 3 такими характеристиками, як: теплий, доброзичливий, приємний, мав вищий рівень привабливості, ніж чоловічий голос консультанта, незалежно від віку цього голосу. Також дослідники дійшли висновку, що учасники експерименту віддавали перевагу голосу віртуального консультанта, який був емоційно виразний i максимально схожий на реальний людський голос, той, що викликав симпатію [19]. Згідно 3 результатами цього дослідження, цілком очевидним $є$ той факт, що для клієнтів важливим чинником ефективності психологічного консультування виступають атрактивні характеристики мовлення психолога, чи то реального, чи віртуального.

Отже, дослідження, присвячені ролі атрактивності в консультаційній діяльності психолога, свідчать про те, що зазначена особистісна якість психолога вивчалась багатьма науковцями, визна- чались чинники, що викликають прихильності до особистості психолога, встановлювалась співвіднесення атрактивності 3 іншими професійними характеристиками психолога, виявлялись особли-

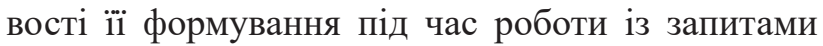
клієнтів різної типології. Досить уваги було приділено саме аналізу вербальної поведінки (саморозкриття, відкритість, звернення на ім'я, схожість ставлення та виразність голосу психолога) як такої, що посилює атрактивність психолога в очах клієнта. Крім того, було визначено, що високий рівень сприйнятливої невербальної поведінки також позитивно сприяє зростанню атрактивності психолога-консультанта.

Висновки. Проведений теоретичний аналіз наукових досліджень щодо особливостей прояву атрактивності у професійній діяльності психолога-консультанта дозволяє сформулювати завдання на перспективу. Відсутність чіткого визначення поняття «атракційність психолога» зумовлює необхідність проведення грунтовного емпіричного дослідження уявлень про атракційність психолога серед клієнтів психологічного консультування, психологів-практиків та майбутніх психологів, чинників, що запускають механізм виникнення зазначеної особистісної якості, рівня iii впливу на результативність психологічного консультування.

\section{Список літератури:}

1. Большой психологический словарь. Москва : Прайм-Еврознак, 2003. С. 48-49.

2. Васьківська С. Основи психологічного консультування : навчальний посібник. Київ : Ніка-Центр, 2011. 242 c.

3. Вачков И. Основы технологии группового тренинга. Психотехники. Москва : Ось-89, 2008. 256 с.

4. Верещинська Я. Привабливість як естетичний компонент соціальної перцепції. Психологія $і$ особисmicmb. 2016. № 1. С. 245-253.

5. Кленчу А. Емоційно-комунікативні особливості атрактивності та їх корекція у дівчат старшого юнацького віку: автореф. дис. ... канд. психол. наук: 19.00.07. Одеса, 2011. 20 с.

6. Консультативна психологія : підручник / І. Булах та ін. Вінниця : Нілан, 2014. С. 162-177.

7. Кочюнас Р. Психологическое консультирование. Москва : Академический проект, 2020. 222 с.

8. Мещеряков Б., Ющенкова Д. Глаза как предикторы воспринимаемой физической аттрактивности женских лиц. Культурно-историческая психология : международный научный журнал. 2006. № 1. С. 48-56.

9. Мэй Р. Искусство психологического консультирования. Институт общегуманитарных исследований. Санкт-Петербург : Апрель-Пресс, 2015. С. 70.

10. Олифирович Н. Индивидуальное психологическое консультирование : теория и практика. Минск : Тесей, 2005. С. 110-111.

11. Сердюк Н. Психологічні умови формування атракції до однолітків у підлітковому віці : автореф. дис. ... канд. психол наук: 19.00.07. Бердянськ, 2014. 23 с.

12. Хомич Г., Шамардак Ю. Атракція як складова міжособистісної перцепції у професійній діяльності психолога. Humanitarium. 2019. Т. 42. Вип. 1. С. 189-197.

13. Шахматова О. Педагогическая фасилитация: особенности формирования и развития. Haучные исследования в образовании. 2006. № 3. С. 118-125.

14. Bahari S., Saad M., Salleh A. Clients' perception of counseling variables in relation to counseling outcomes. Malaysia Online Journal of Psychology \& Counselling. 2017. 2.2. URL: https://www.researchgate.net/ publication/271589378. 
15. Barak A., Patkin J., Dell D. Effects of certain counselor behaviors on perceived expertness and attractiveness. Journal of Counseling Psychology. 1982. № 29 (3). P. 261-267.

16. Dowd E., Boroto D. Differential effects of counselor self-disclosure, self-involving statements, and interpretation. Journal of Counseling Psychology. 1982. № 29 (1). P. 8-13.

17. Gladding S. Counseling: A Comprehensive Profession. 8'th Edition. Wake Forest University : Pearson, 2018. P. 159.

18. Harris St., Busby D. Therapist physical attractiveness: an unexplored influence on client disclosure. Journal of Marital and Family Therapy. April 1998. Vol. 24. Iss. 2. P. 251-257.

19. Kim H., Cha M., Ji Y. The Impact of an Agent's Voice in Psychological Counseling: Session Evaluation and Counselor Rating. Appl. Sci. 2021. № 11. P. 2893.

20. La Crosse M. Nonverbal behavior and perceived counselor attractiveness and persuasiveness. Journal of Counseling Psychology. 1975. № 22 (6). P. 563-566.

21. The influence of physical attractiveness on attitude confidence and resistance to change / J. Melloa et al. Journal of Experimental Social Psychology. September 2020. Vol. 90. P. 104018.

22. Miller M., Wells D. On Being "Attractive" With Resistant Clients. Journal of Humanistic Education and Development. Dec 1990. V. 29. № 2. P. 86-92.

23. Nerison R., Claiborn Ch. Counselor Attractiveness, Similarity, and Session impac t: A Field Study. Paper presented at the Annual Convention of the American Psychological Association, 98'th, Boston, MA, August 11-14, $1990.38 \mathrm{p}$.

24. Robbins E., Haase R. Power of nonverbal cues in counseling interactions: Availability, vividness, or salience? Journal of Counseling Psychology. 1985. № 32 (4). P. 502-513.

25. Judging attractiveness: Biases due to raters' own attractiveness and intelligence / S. Sim et al. Cogent Psychology. 2015. № 2. P. 996316.

26. Störmer V., George A. Attention Alters Perceived Attractiveness. Psychological Science. 2016. 27. № 4. P. 563-71.

27. Strong S., Claiboru C. Change through interaction: Social psychological processes of counseling and psychotherapy. New York : Wiley, 1982. 259 p.

\section{Serdiuk N.I. ATTRACTION AS A GUARANTEE OF EFFECTIVE COUNSELING ACTIVITIES OF A PSYCHOLOGIST}

The article considers the importance of the attractiveness of the psychologist in the implementation of effective counseling with clients. The meaning of the concept of "attraction' is given, which means a person's ability to evoke sympathy and trust in other people. Theoretical analysis of researches of scientists in which features of display of attractiveness of the psychologist are studied, the factors causing attachments to the personality of the psychologist are defined, correlation of attractiveness with other professional characteristics of the psychologist is established. The influence of the attractiveness of the psychologist in consulting work with complex clients and their psychological protection mechanisms is noted. As a result of generalization, it is determined that the attractiveness of a psychologist depends on his personal attitude to the counseling process, the ability to attract people to himself, to feel free during the consultation, to show the ability to empathize. The most significant verbal forms of behavior (self-disclosure of the psychologist, manifestation of similarity of life values, address to the client, expressiveness of the psychologist's speech, etc.) and nonverbal forms of behavior (positive nods, hand gestures, handshake, eye contact, facial expression, facial expressions) etc.) that positively and effectively affect the attractiveness of the psychologist and psychological counseling. The results of a modern study on the attractiveness of the voice of a virtual consultant (chatbot), who acts as a psychologist and conducts psychological counseling with real people. The task for the future is defined, which consists in a thorough empirical study of ideas about the attractiveness of a psychologist among clients of psychological counseling, practicing psychologists and future psychologists and its impact on the effectiveness of counseling.

Key words: attractiveness, psychologist, counseling, verbal behavior, nonverbal behavior. 